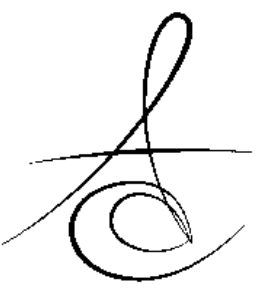

\title{
EFFECT OF THE TYPE OF THE ANESTHETIC SOLUTION ON THE INCIDENCE OF PULP NECROSIS FOLLOWING CROWN PREPARATION: A RANDOMIZED CLINICAL STUDY
}

\section{KURON PREPARASYONUNU TAKİBEN GÖRÜLEN PULPA NEKROZUNA ANESTEZİ SOLÜSYONU TİPINİN ETKİSİ: BİR RANDOMİZE KLİNİK ÇALIŞMA}

\author{
Doç. Dr. Ertuğrul KARATAŞ* \\ Dr. Esra ULUKÖYLÜ*
}

\author{
Dr. Öğr. Üyesi Mustafa GÜNDOĞDU** \\ Dr. Öğr. Üyesi Rüştü Ersoy SAKARYA**
}

Makale Kodu/Article code: 3872

Makale Gönderilme tarihi: 07.11.2018

Kabul Tarihi: 25.07.2019

\section{ABSTRACT}

Aim: The objective of the present study was to evaluate the effect of the type of the anesthetic solution (with or without epinephrine) on the development of pulp necrosis after tooth preparation.

Methods: Seventy-two patients were randomly allocated into 2 groups according to the type of the anesthetic solution used. In the first group, 4\% articaine with 1:100.000 epinephrine was used as local anesthesia and in the second group, 3\% plain mepivacaine was used. Before administration of the anesthetic solution, electric pulp tester (EPT) and cold test were used to test the vitality of the teeth. The teeth were then prepared and provisional crowns were fabricated chairside. After 15 days, the provisional crowns were removed and then the EPT procedures and cold test were repeated. Postoperative pain level on days 1, 3, 5 and 15 were recorded. The EPT scores and pain levels were statistically analyzed.

Results: A statistically significant difference was observed between the groups in terms of percentage change in EPT scores.

Conclusion: The type of the anesthetic solution does not affect the vitality of the teeth after full-crown preparation.

Keywords: Anesthetic solution, Pulp necrosis, Articaine, Mepivacaine

\section{öz}

Amaç: Bu çalışmanın amacl, diş preparasyonu sonrası gelişen pulpa nekrozu üzerine kullanılan anestezi solüsyonunun etkisini değerlendirmektir.

Metod: 72 hasta kullanılacak anestezi solüsyonu tipine göre rastgele olarak 2 gruba ayrıldı. Birinci grupta lokal anestezi olarak $1 / 100000$ epinefrinli $\% 4$ 'lük articaine kullanıldı ve ikinci grupta \%3 sade mepivacaine kullanıldı. Anestez uygulamasından önce elektrikli pulpa testi (EPT) ve soğuk testi kullanılarak dişlerin vitalitesi test edildi. Daha sonar diş preparasyonu yapıldı ve geçici kuronlar uygulandı. 15 gün sonar geçici kuronlar söküldü ve EPT ve soğuk testi prosedürleri tekrarlandı. Tedaviden sonraki 1., 3., 5. ve 15. günlerde ki postoperative ağrı değerleri kaydedildi. EPT değerleri ve ağrı skorları istatistiksel olarak analiz edildi.

Bulgular: Gruplar arasında EPT yüzdelik değişimleri açısından istatistiksel olarak anlamlı farklılık olduğu gözlemlendi.

Sonuç: Kullanılan anestezi solüsyonu tipi, tam kuron preparasyonu sonrası dişlerin canlıı̆ını etkilememektedir.

Anahtar kelimeler: Anestezi solüsyonu, Pulpa nekrozu, Articaine, Mepivacaine

\footnotetext{
*Department of Endodontics, Faculty of Dentistry, Atatürk University, Erzurum.

** Department of Prosthodontics, Faculty of Dentistry, Atatürk University, Erzurum.
} 


\section{INTRODUCTION}

The ratio of teeth becomes necrotic after tooth preparation for full coverage crowns is between $15 \%$ and $25 \%{ }^{1,2}$. Several reasons have been asserted to clarify the necrosis of pulp after tooth preparation ${ }^{3}$ such as heat generation during cutting procedures if the water-cooling is not adequate ${ }^{4}$, the pressure performed to the dentin during cutting even when the water cooling of the tooth is adequate effective ${ }^{5}$ and toxic influences of medicaments and materials performed on the freshly cut dentine surface ${ }^{6,7}$.

Some pulp tests are subjective which involve electrical or thermal stimulation of a tooth to determine whether the pulpal nerves are functional. In the other hand, there are some objective pulp tests such as Laser Doppler Flowmetry (LDF) using devices to detect pulpal vascularity ${ }^{8}$. It is well known that detection of the pulpal blood flow (PBF) is the true determinant of pulp vitality ${ }^{9-12}$. Previously, Kim et al ${ }^{13}$ have evaluated the effect of drilling dentine on the amount of PBF using a radio-labelled injection technique and reported $13 \%$ and $34 \%$ reduction in PBF with or without water-cooling respectively. Moreover, one hour after drilling the reduction was around $89 \%$. Decrease in PBF may result in vitality loss because the most accepted theory in pulp canal obliteration is that change in PBF results in uncontrolled reparative dentin formation and entire root canal becomes obliterated.

The most common forms of injectable local anesthetics used in dentistry are in amid class. Some of amid anesthetics are articaine, lidocaine, mepivacaine and bupivacaine which are commonly used in Endodontics. To increase anesthetic efficacy, local anesthetics including vasoconstrictor (epinephrine) are recommended ${ }^{14}$. It has been stated that the vasoconstrictor presents in the local anesthesia may also change the amount of PBF ${ }^{15}$. However, to date, no study has evaluated the effect of vasoconstrictor presents in local anesthetic on the vitality loss of tooth after full crown preparation. Therefore, the present study aimed to evaluate the effect of the type of the anesthetic solution (with or without epinephrine) on the development of pulp necrosis after tooth preparation. The null hypothesis was that the type of the anesthetic solution does not affect the ratio of the vitality loss of teeth and postoperative pain level after tooth preparation.

\section{MATERIALS AND METHODS}

The decision number of the ethical approval was 2016-58. A written consent was obtained from the participants before undergoing the treatment. Since a minimum sample size of 27 subjects for per group was calculated using the G*Power software (GPower; Franz Faul, University of Kiel, Germany) (a power of 0.8 , an a of 0.05 , an effect size of 0.5 ), the study included a total of 72 patients.

Healthy patients without any systemic diseases or allergic reactions (American Society of Anesthesiology [ASA] I) with healthy intact incisor, canine or premolar teeth that will form the abutments for fixed partial denture were included to the study. Exclusion criteria were as follows: molar teeth, patients who are younger than 18 or older than 65 years old, and taking analgesics or antibiotics within one month prior to the study.

A web program was used to randomly assign seventy-two participants into 2 groups using (www.randomizer.org) according to the anesthetic solutions (3\% plain mepivacaine or $4 \%$ articaine with 1:100.000 epinephrine). A dental assistant put the anesthetic solution into the syringe before treatment to effectively blind the practitioner and patient to the local anesthetic solution. Before administration of the anesthetic solution, electric pulp tester (EPT) (Digitest, Parkell, Edgewood, NY, USA) and cold test (Roeko Endo Frost, Coltene, Langenau, Germany) were used to test the vitality of the teeth. After isolation of the related tooth with cotton rolls, the tooth was dried and EPT test which has readings range from 0 to 64 was performed. The buccal cusp tip of premolars and the incisal edge of anterior teeth was selected for the placement of the probe of EPT and selected area was coated with a small amount of toothpaste before testing. The mean value of three EPT readings was recorded. Additionally, the EPT test was performed on contralateral tooth (as control tooth) to re-evaluate the EPT readings. Before the teeth preparation, local infiltration anesthesia was performed for all teeth. The fixed partial dentures were of the porcelain fused to metal type. Approximately, $1 \mathrm{~mm}$ from the distal, mesial and lingual surfaces and $1.2 \mathrm{~mm}$ from the buccal and $2 \mathrm{~mm}$ from the occlusal surfaces was removed using high-speed diamond burs under water spray coolant. The finish line of the teeth preparation

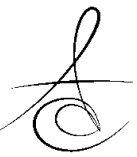


was formed chamfer and subgingival (located approximately $0.5 \mathrm{~mm}$ below the gingival margin). After teeth preparations, provisional crowns were fabricated chairside for abutment teeth using autopolymerizing composite resin (Structur 2, Voco $\mathrm{GmbH}$, Cuxhaven, Germany) and was cemented to the teeth using a provisional luting agent (Life Regular Set, Kerr, Salerno, Italy). After 15 days, the provisional crowns were removed and the EPT procedures were repeated. After the evaluation of marginal seating, occlusal interference and esthetic, the fixed partial dentures were cemented using a glass ionomer cement (Meron, Voco GmbH, Cuxhaven, Germany).

To compare postoperative pain level between the groups, the participants were given directions to record postoperative pain level on days $1,3,5$ and 15 using a visual analog scale with a length of $10-\mathrm{cm}$ (VAS). Gender, age and tooth number were also recorded.

The study data were analyzed using a program (IBM SPSS Inc., Chicago, IL, USA). Linear regression analysis was carried out to detect the most effective factor (group, tooth number, age and sex) related with the percentage change between preoperative and postoperative EPT scores. Only the data for age were normally distributed and homogenous and the rest of the data (EPT scores and pain levels) were not. For intra-group analysis, the Wilcoxon test was used to compare preoperative and postoperative EPT scores. For inter-group analysis, the Mann-Whitney $U$ test was used to compare the percentage changes between preoperative and postoperative EPT scores, and postoperative pain level on days $1,3,5$, and 15 . To compare gender and tooth number between the groups the chi-square test and to compare age between the groups independent samples t-test was carried out. The significance level for all tests was set at $5 \%(p=0.05)$.

\section{RESULTS}

Since 2 patients from 3\% mepivacaine group were lost during follow-up, a total of 70 patients were included into the study (Figure 1). Demographic features according to the groups are shown in Table 1. The difference between the groups in terms of gender, tooth number, or age was not statistically significant $(P>0.05)$.
Table 1. Dispersion of participants according to age, gender and tooth number

\begin{tabular}{|c|c|c|c|}
\hline & $\begin{array}{l}\text { 4\% Articaine } \\
(1: 100.000)\end{array}$ & $\begin{array}{l}3 \% \\
\text { Mepivacaine }\end{array}$ & $\begin{array}{l}P \\
\text { value }\end{array}$ \\
\hline$N$ & 36 & 34 & \\
\hline $\begin{array}{l}\text { Mean Age } \\
\text { Gender }\end{array}$ & $43.28 \pm 11.60$ & $44.38 \pm 10.40$ & $\begin{array}{l}0.677 \\
0.299\end{array}$ \\
\hline Female & 20 & 23 & \\
\hline Male & 16 & 11 & \\
\hline Tooth Number & & & 0.227 \\
\hline \#4 & 1 & 1 & \\
\hline \#5 & 1 & 3 & \\
\hline \#6 & 3 & 3 & \\
\hline \#7 & 0 & 2 & \\
\hline \#8 & 1 & 4 & \\
\hline$\# 9$ & 2 & 6 & \\
\hline \#10 & 2 & 2 & \\
\hline \#11 & 7 & 4 & \\
\hline \#12 & 3 & 2 & \\
\hline \#13 & 4 & 0 & \\
\hline \#20 & 2 & 2 & \\
\hline \#21 & 3 & 0 & \\
\hline \#22 & 2 & 1 & \\
\hline \#23 & 0 & 1 & \\
\hline \#25 & 0 & 1 & \\
\hline \#26 & 2 & 0 & \\
\hline \#27 & 2 & 0 & \\
\hline \#28 & 1 & 1 & \\
\hline \#29 & 0 & 1 & \\
\hline
\end{tabular}

Linear regression analysis revealed that the percentage change between the pre- and posttreatment EPT scores were not affected by the age, gender and tooth number $(P>0.05)$. However, the type of the anesthetic solution affected the percentage change between the preoperative and postoperative EPT scores $(P<0.05)$. Table 2 shows the linear regression analysis findings.

Table 2. Linear Regression findings for group, gender, age and tooth number on the dependent variable "percentage change between preoperative and postoperative EPT scores"

\begin{tabular}{|l|c|l|l|l|}
\hline & B $^{*}$ & Standard Error & Beta & P value \\
\hline Group & -59.466 & 20.565 & -0.332 & 0.005 \\
\hline Gender & 32.097 & 26.056 & 0.174 & 0.222 \\
\hline Age & 1.28 & 1.163 & 0.156 & 0.275 \\
\hline Tooth Number & -0.603 & 1.128 & -0.065 & 0.595 \\
\hline
\end{tabular}

According to the intragroup analyses, although the post-treatment EPT scores of $4 \%$ Articaine (1:100.000) group were significantly lower than the pre-treatment EPT scores $(P<0.05)$, in the $3 \%$ Mepivacaine group, the difference between the preoperative and postoperative EPT readings was not statistically significant $(P>0.05)$ (Table 3).

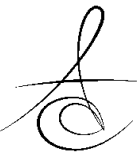


Table 3. EPT scores according to the groups

\begin{tabular}{llr}
\hline & $\begin{array}{l}\mathbf{4 \%} \quad \text { Articaine } \\
(\mathbf{1 : 1 0 0 . 0 0 0 )}\end{array}$ & $\begin{array}{c}\mathbf{3 \%} \\
\text { Mepivacaine }\end{array}$ \\
\hline $\begin{array}{l}\text { Preoperative } \\
\begin{array}{l}\text { Postoperative } \\
\text { (15th Day) }\end{array}\end{array}$ & $1.88 \pm 1.17$ & $1.44 \pm 0.96$ \\
\hline $\boldsymbol{P}$ value & $0.74 \pm 0.31$ & $1.06 \pm 0.94$ \\
\hline
\end{tabular}

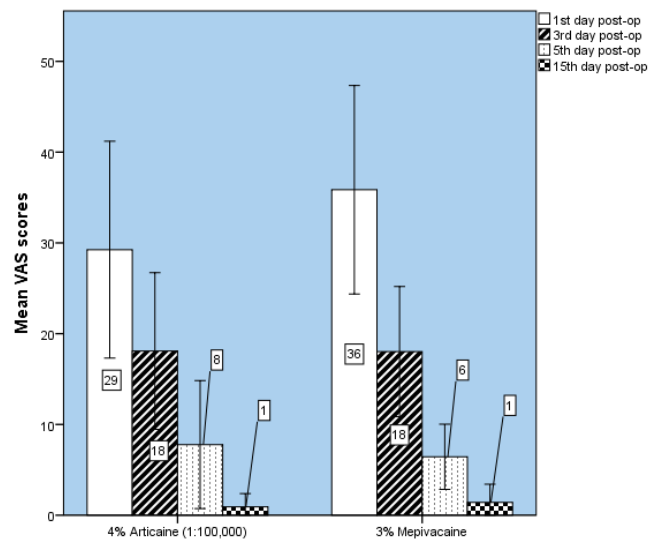

Figure 1. Flow diagram

For intergroup analyzing, pre-preparation and post-preparation percentage change in EPT scores were compared and it has been revealed a statistically significant difference between the $4 \%$ Articaine $(1: 100.000)$ and $3 \%$ Mepivacaine groups in terms of percentage change in EPT scores $(P<0.05)$. The percentage change was higher in the $4 \%$ Articaine $(1: 100.000)$ group means that the $4 \%$ Articaine $(1: 100.000)$ group lowered preoperative EPT scores more than the 3\% Mepivacaine group did (Figure 2).

Postoperative pain levels between the groups were not statistically different at any time intervals $\left(1^{\text {st }}, 3^{\text {rd }}, 5^{\text {th }}\right.$, and $15^{\text {th }}$ days $)(P>0.05)$ (Figure 3$)$.

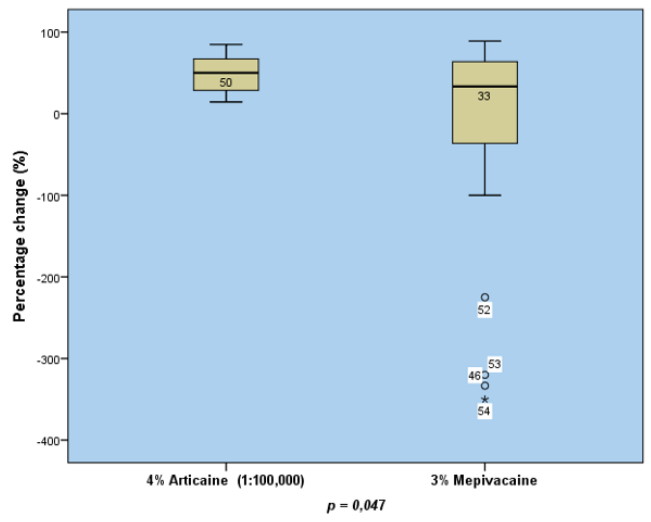

Figure 2. Box plots show preoperative-postoperative percentage change of EPT scores for the groups

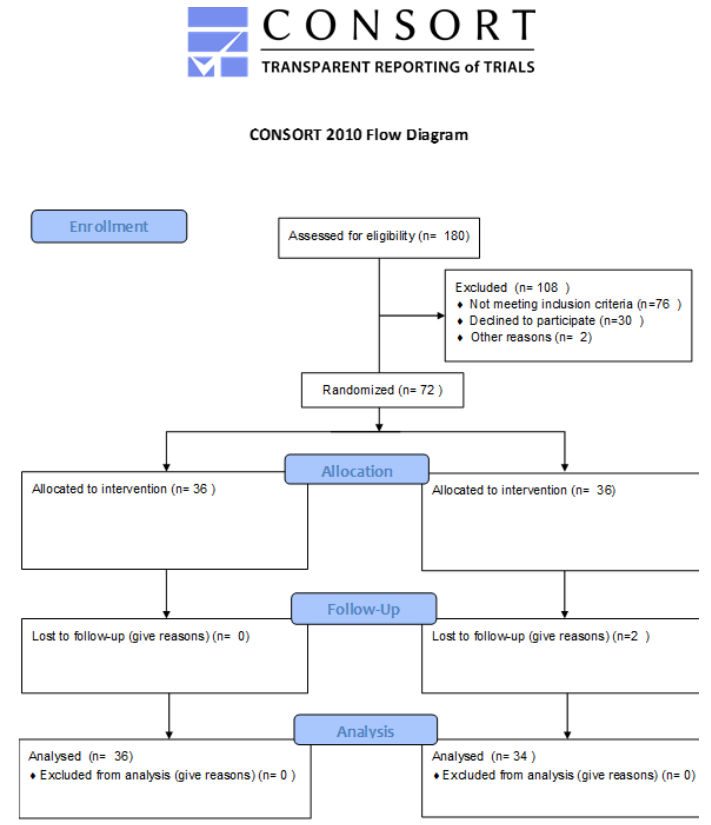

Figure 3. Postoperative mean VAS scores according to the groups

\section{DISCUSSION}

This study has shown that the type of the anesthetic solution affects the post-treatment EPT score. However, both the ratio of the vitality loss of teeth after tooth preparation and post-operative pain level have not been effected by the type of the anesthetic solution. Thus, the null hypothesis was accepted.

Previously several studies have reported pulpal necrosis after crown preparation 2, 5, 16. On the contrary, in the present experiment, none of the tooth has become necrotic. This was probably due to the difference in experimental design between the present study and the previous ones. Langeland et al. reported that crown preparation does not cause a pulpal reaction if the water cooling is sufficient. In addition, in the present study, intact teeth were included to the study and intact teeth have a significantly lower incidence of pulp necrosis (5\%) ${ }^{16}$. However, according to the result of the present study, in the $4 \%$ Articaine (1:100.000) group post-treatment EPT scores were significantly lower than the preoperative EPT scores. In contrast, in the 3\% Mepivacaine group, the difference between the pre-treatment and posttreatment EPT scores was not statistically significant. This is an important finding because it is well known

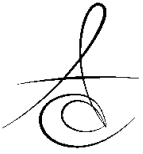


that vasoconstrictor present in local anesthesia causes a decrease in PBF ${ }^{17}$ and this situation would result in a restricted blood source in the pulp. It is more likely that the restricted blood source limits the pulpal blood flow and makes the pulp less capable of overcoming an irritant ${ }^{18}$. Consequently, pulp inflammation may develop. In the development of pulp inflammation, inflammatory mediators are synthesized that may excite nerve fibers in the pulp resulting in a hyperalgesia ${ }^{19}$. This may explain the post-operative sensitivity of the teeth to EPT in the $4 \%$ Articaine $(1: 100.000)$ group. Although, the degree of pulp inflammation does not need to be severe to result in pulpal necrosis ${ }^{18}$, none of the teeth has become necrotic in the present study. This may be explained by the fact that preparation procedures irritate the pulp and induce a slow, progressively developing tissue degeneration in the pulp resulting in broad secondary dentin accumulation within the pulp ${ }^{2}$ as can be seen in a traumatized tooth in which the tooth may stay vital for a considerable period of time but late development of pulp necrosis can be occur suddenly several years after the trauma ${ }^{20,21}$.

In the present study, the effect of the type of anesthetic solution on post-operative pain level was also investigated. According to the results, the difference between the groups in terms of postoperative pain level was not statistically significant. Previously, there are no study evaluating the effect of the type of anesthetic solution on post-operative pain level. Thus, a direct comparison cannot be done. Kara et al ${ }^{22}$ have evaluated the effect of the gluma and diode laser on postoperative sensitivity. They reported a significant reduction in post-preparation sensitivity level in both groups when compared with the control. However, they evaluated pain response to tactile stimulus which is correlated with the diameter and number of exposed dentine tubules ${ }^{23}$. In the present study, post-preparation spontaneous pain, correlated with pulpal inflammation, was evaluated. It is likely that pulpal inflammation was reversible because none of the teeth become necrotic. This may explain the result of the present study.

In the present study, EPT and cold test was used to evaluate the vitality of the samples. However, EPT readings were only used for statistical test. Cold test scores were not included to statistical analyses because it is more like that after preparation the teeth become more sensitive to cold test because of exposed dentinal tubules ${ }^{23}$.

It is well known that EPT is a subjective test which assess the function of pulp nerves. It is impossible to detect pulpal blood flow by using EPT. This is the most important limitation of the present study. An objective test LDF can be used for the determination of PBF. However, there are conflicting reports about the accuracy of LDF in determining PBF. A recent systematic review revealed that LDF and pulse oxymetry were the most accurate diagnostic methods in testing vitality of teeth ${ }^{24}$. In contrast, Ghouth et al ${ }^{25}$ conducted a clinical study evaluating the accuracy of LDF and reported that LDF is unable to differentiate between teeth with vital and non-vital pulps. Additionally, they mentioned that, some further developments are needed in terms of assessing pulpal blood flow with LDF, before clinical use of it.

According to the result of the present study, it can be concluded that the type of the anesthetic solution does not affect the vitality of the teeth after full-crown preparation. Using 4\% Articaine (1:100.000) solution for anesthesia makes teeth more sensitive to EPT when compared with $3 \%$ Mepivacaine. The type of the anesthetic solution does not affect the post-preparation pain level.

Ertuğrul Karataş: ORCID ID: 0000-0002-8145-8763

Mustafa Gündoğdu: ORCID ID: 0000-0003-2527-0392

Esra Uluköylü: ORCID ID: 0000-0002-1569-6528

Rüştü Ersoy Sakarya: ORCID ID: 0000-0002-2289-3896

\section{REFERENCES}

1 Cheung GS, Lai SC, Ng RP. Fate of vital pulps beneath a metal-ceramic crown or a bridge retainer. Int Endod J 2005; 38: 521-30.

2. Bergenholtz G, Nyman S. Endodontic complications following periodontal and prosthetic treatment of patients with advanced periodontal disease. J Periodontol. 1984; 55: 63-8.

3. Acar Ö, Erkut, S. Tooth preparation and pulpal response: Literature Review. Atatürk Üniv Diş Hek Fak Derg 2013; 23: 282-8.

4. Langeland $\mathrm{K}$, Langeland LK. Pulp reactions to crown preparation, impression, temporary crown fixation, and permanent cementation. J Prosthet Dent 1965; 15: 129-43.

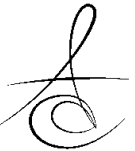


5. Stanley HR, Swerdlow H. Biological effects of various cutting methods in cavity preparation: the part pressure plays in pulpal response. J Am Dent Assoc 1960; 61: 450-6.

6. Frank RM. Reactions of dentin and pulp to drugs and restorative materials. J Dent Res 1975; 54: 176-87.

7. Brannstrom M. Dentin and pulp in restorative dentistry; Dental Therapeutics AB. J Endod 1982; 8: 98.

8. Louis $\mathrm{H}$ Berman. Diagnosis. In: Kenneth Hargreaves. Louis H Berman, ed. Cohen's pathways of the pulp. 11 ed; 2016. pp. 15.

9. McMorrow RC, Mythen MG. Pulse oximetry. Current opinion in critical care. 2006; 12: 269-71.

10. Calil E, Caldeira CL, Gavini G, Lemos EM. Determination of pulp vitality in vivo with pulse oximetry. Int Endod J 2008; 41: 741-6.

11. Gopikrishna V, Tinagupta K, Kandaswamy D. Evaluation of efficacy of a new custom-made pulse oximeter dental probe in comparison with the electrical and thermal tests for assessing pulp vitality. J Endod 2007; 33: 411-4.

12. Bozdağ G, Şener, S. Pulp Vitality Testings: Review. Atatürk Üniv Diş Hek Fak Derg 2015; 13: 57-63.

13. Kim S, Dorscher-Kim J, Baek SH. Effects of tooth preparation and dental materials on pulpal microcirculation: Shunting of $9 \mu$ and $10 \mu$ microspheres. Proceedings of the International Conference on Dentine/pulp Complex 1995 and the International Meeting on Clinical Topics of Dentine/pulp Complex 1996: 58-61.

14. Al Reader JN, . Asma Khan. Pain Control. In: Kenneth Hargreaves. Louis H Berman, ed. Cohen's pathways of the pulp. 11 ed; 2016. pp. 103.

15. Kim S. Ligamental injection: A physiological explantation of its efficacy. J Endod 1986; 12: 48691.

16. Kontakiotis EG, Filippatos CG, Stefopoulos S, Tzanetakis GN. A prospective study of the incidence of asymptomatic pulp necrosis following crown preparation. Int Endod J 2015; 48: 512-7.

17. Odor TM, Pitt Ford TR, McDonald F. Adrenaline in local anaesthesia: the effect of concentration on dental pulpal circulation and anaesthesia. Endod Dent Traumatol 1994; 10: 167-73.
18. Yu C, Abbott PV. An overview of the dental pulp: its functions and responses to injury. Aust Dent J 2007; 52: S4-16.

19. Okiji T, Morita I, Kawashima N, et al. Immunohistochemical detection of prostaglandin I2 synthase in various calcified tissue-forming cells in rat. Arch Oral Biol 1993; 38: 31-6.

20. Jacobsen I, Kerekes K. Long-term prognosis of traumatized permanent anterior teeth showing calcifying processes in the pulp cavity. Scandinavian J Dent Res 1977; 85: 588-98.

21. Lundberg M, Cvek M. A light microscopy study of pulps from traumatized permanent incisors with reduced pulpal lumen. Acta Odontol Scand 1980; 38: 89-94.

22. Kara HB, Cakan U, Yilmaz B, Inan Kurugol P. Efficacy of diode laser and gluma on postpreparation sensitivity: a randomized split-mouth clinical study. J Esthet Restor Dent 2016; 28: 40511.

23. Richardson D, Tao L, Pashley DH. Dentin permeability: effects of crown preparation. Int J Prosthodont 1991; 4: 219-25.

24. Mainkar A, Kim SG. Diagnostic Accuracy of 5 dental pulp tests: a systematic review and meta-analysis. J Endod 2018; 44: 694-702.

25. Ghouth N, Duggal MS, Kang J, Nazzal H. A diagnostic accuracy study of laser doppler flowmetry for the assessment of pulpal status in children permanent incisor teeth. J Endod 2019; 45:543-8.

\section{Yazışma Adresi}

Ertuğrul Karataş

Department of Endodontics, Faculty of Dentistry, Atatürk University,

Erzurum, 25240, Turkey

Business telephone number: +90.442 .2313804$

E-mail address: dtertu@windowslive.com 